\title{
Metformin-Induced Alterations In Gills Of The Freshwater Fish Astyanax Lacustris (Lütken, 1875) Detected By Histological And Scanning Electron Microscopy
}

Pablo Barbieri ( $\sim$ pabloambarbieri@gmail.com )

Universidade Estadual de Maringa https://orcid.org/0000-0003-3288-8748

Isabelle Pereira Mari-Ribeiro

Universidade Estadual de Maringa

Luara Lupepsa

Universidade Estadual de Maringa

Adriana Aparecida Sinópolis Gigliolli

Universidade Estadual de Maringa

Brennda Ribeiro Paupitz

Universidade Estadual de Maringa

Rafael Fernando de Melo

Universidade Estadual de Maringa

Eneri Vieira de Souza Leite Mello

Universidade Estadual de Maringa

Ana Luiza de Brito Portela-Castro

Universidade Estadual de Maringa

Luciana Andreia Borin-Carvalho

Universidade Estadual de Maringa

\section{Research Article}

Keywords: Antidiabetic, Ecotoxicology, Biomarkers, Respiratory epithelium.

Posted Date: February 24th, 2022

DOI: https://doi.org/10.21203/rs.3.rs-1280750/v1

License: (1) This work is licensed under a Creative Commons Attribution 4.0 International License. Read Full License 


\section{Abstract}

The antidiabetic drug metformin is widely prescribed and found in high concentrations in the environment around the world, raising concern about potential impacts on aquatic life. Fish have a fundamental ecological role and are considered excellent experimental models in ecotoxicology studies. Gills of fish are extremely sensitive to even minor chemical or physical changes in the surroundings, mainly because of the large surface of the respiratory epithelium and the high perfusion rate, which both facilitate the entry of pollutants into this tissue. This study aimed to evaluate the occurrence of morphological changes in the gills of Astyanax lacustris exposed to metformin. The animals were subjected to different concentrations of the drug (50 ug/L, $100 \mathrm{ug} / \mathrm{L}, 1 \mathrm{mg} / \mathrm{L}$ and $10 \mathrm{mg} / \mathrm{L}$ ) for a period of 90 days. Histopathological analyses were performed using light and Scanning Electron Microscopy. The main changes were lamellar fusion, telangiectasia hyperplasia and disappearance of microridges. The observed effects occurred at environmentally relevant concentrations, pointing to a concern that metformin may pose a risk to Astyanax lacustris and likely to other fish species.

\section{Introduction}

Aquatic ecosystems are the main recipients of contaminants (Abhilash, 2012; Patel et al., 2019). Many drugs consist of organic compounds that are not easily biodegraded, and these compounds are unaltered by conventional treatment in Water Treatment Plants (WTP) or Sewerage systems (WTS) before being discarded into the environment (Santos et al., 2010; Stuart et al., 2012). Different therapeutic classes of drugs, including hypoglycemic agents, analgesics, antibiotics, hormones and antihypertensives, have been detected in waste and surface water at variable concentrations (Shao et al., 2009; Ibáñez et al., 2013; Oosterhuis et al., 2013; Santos et al., 2013; Bradley et al., 2016). However, only a small number of pharmaceutical products found in wastewater treatment plant effluents have been studied for environmental impacts (Heberer, 2002; Fatta-Kassinos et al., 2011). Among them, the antidiabetic drug metformin, belonging to the biguanide class, is considered the drug that is most deposited in the aquatic environment (MacLaren et al., 2018). The human body does not metabolize metformin and, therefore, approximately $90 \%$ of the therapeutic dosage is excreted in its original form (Dumitrescu, et al. 2015).

The presence of metformin in the environment can be attributed to widespread medical prescription for the prevention of chronic diseases, including diabetes mellitus type II, treatment of polycystic ovary syndrome and some cancers (Sahra et al., 2010; Johnson, 2014; Saraei, et al., 2019). The detected concentrations vary from 39 $\mu \mathrm{g} / \mathrm{L}$ to $56 \mu \mathrm{g} / \mathrm{L}$ in surface water (Oosterhuis et al., 2013), $57 \mu \mathrm{g} / \mathrm{L}$ to $129 \mu \mathrm{g} / \mathrm{L}$ in raw wastewater (Scheurer et al., 2009; Trautwein and Kümmerer, 2011; Scheurer et al., 2012) and 720 $\mathrm{g} / \mathrm{L}$ in hospital sewers (Ribeiro et al., 2006). In Germany, metformin has also been detected in seawater and drinking water, which demonstrates the absence of efficient degradation processes, both in oceanic environments and in drinking water treatment plants, suggesting the high persistence and wide distribution potential of this drug (Trautwein et al., 2014).

Studies (Ambrosio-Albuquerque et al., 2021) on the impact of metformin on fish have shown its effects at different levels. In Pimephales promelas, metformin caused the development of intersex gonads and induction of vitellogenin expression, among other genes involved in estrogen biosynthesis, indicating its potential as an endocrine disruptor (Niemuth and Klaper 2015; Crago et al., 2016). In the species Betta splendens (beta fish), metformin caused changes in aggressive behavior, with the potential to affect male reproductive fitness and possibly affect species survival (Maclaren et al., 2018). Meador et al. (2018) investigated the effects of emerging 
contaminants, including metformin, on two fish species (Oncorhynchus tshawytscha and Leptocottus armatus), and observed that metformin can inhibit animal growth and alter some metabolic pathways.

In zebrafish (Danio rerio) toxicity studies, based on hatching, survival and growth rates, the no observed effect concentration (NOEC) for metformin was from 10mg/L in chronic tests (Moermond and Smit, 2016). The widespread use of Danio rerio in toxicity tests around the world, and also in Brazil, is debatable, since this species does not belong to the Brazilian ichthyofauna.

This study is an important component in the evaluation and understanding of the effects on non-target organisms of a contaminant of environmental significance. Our main aim was to check morphologic alterations in the gills of Astyanax lacustris, a neotropical freshwater fish with wide distribution in the Americas, to determine if there is a relationship between exposure to metformin and the various biological responses, establishing a correlation of sensitive endpoints with population sustainability.

\section{Material And Methods}

\subsection{Obtaining, maintaining and exposing fish to metformin}

Juvenile specimens of Astyanax lacustris (20 to 30 days after hatching) were obtained commercially. The animals were maintained in well-aerated $100 \mathrm{~L}$ tanks containing dechlorinated water, at room temperature $( \pm 25 \rrbracket$ C) with a natural photoperiod and provisioned daily with commercial feed. The fish were distributed into five groups ( $n=50$ fish per group). One group was kept under control conditions only in dechlorinated water and the other four groups were exposed to metformin (CAS No. 1115-70-4 Sigma Aldrich) at concentrations of $50 \mathrm{ug} / \mathrm{L}$, $100 \mathrm{ug} / \mathrm{L}, 1 \mathrm{mg} / \mathrm{L}$ and $10 \mathrm{mg} / \mathrm{L}$ for 90 days, constituting a chronic test. Concentrations of $50 \mathrm{ug} / \mathrm{L}$ and $100 \mathrm{ug} / \mathrm{L}$ were established based on concentrations found and described in the literature for surface water. The concentrations of $10 \mathrm{mg} / \mathrm{L}$ correspond to the NOEC (no observable effect concentration) value described for zebrafish in chronic tests. Metformin replacement was performed twice a week, with the tank water being completely changed (Sharma et al., 2010). All experimental procedures were approved and certified by the Ethics Committee on the Use of Animals (CEUA - State University of Maringá, Paraná, Brazil) under decision number 6409140218.

\subsection{Scanning Electron Microscopy}

For analysis of gills under scanning electron microscopy, three individuals were randomly separated by concentration. The gills were dissected and fixed in aqueous Bouin ( $7.5 \%$ picric acid, $2.5 \%$ formaldehyde, $0.5 \%$ acetic acid) for 24 hours at room temperature. They were serially dehydrated, grown with alcohol $(7.5 \%, 15 \%$, $30 \%, 50 \%, 70 \%, 90 \%$, and $100 \%$ ), critically dried in a Leica CPD030 drier and covered with gold using a Shimadzu IC-50 metalizer. Analyses were performed using a scanning microscope Quanta 250-Fei at the Microscopy Center of the Research Support Centers Complex (COMCAP) at the State University of Maringá, Paraná, Brazil (Gigliolli et al., 2015). The height of the sample is $10 \mathrm{~mm}$ from the detector, accerlating voltage $15.00 \mathrm{KV}$ and the spot was 3.0. The microscope interface program is XT Microscope. Then, qualitative analyses of the gill alterations were carried out. For the capture of microridge images, the primary lamellae were chosen in order to avoid divergence in the location of the tissue where the capture occurred.

\subsection{Light microscopy}

Page $3 / 12$ 
For light microscopy, five individuals were randomly separated by concentration, anesthetized by an overdose of clove oil and manipulated only once they became unresponsive to physical stimuli (approximately 1-2 min) (Inoue et al., 2005). The gills were dissected and fixed in aqueous Bouin's solution (Picric acid 7.5\%, formaldehyde $2.5 \%$, acetic acid $0.5 \%$ ) for $24 \mathrm{~h}$. Samples were dehydrated in a series of increasing concentrations of alcohol $(70 \%, 80 \%, 90 \%$, and $100 \%)$, cleared in xylene, embedded in histological paraffin, and cut into $6 \mu \mathrm{m}$ thick sections with a Leica RM 2250 microtome. The sections were stained with hematoxylin and eosin (HE) (Junqueira and Junqueira, 1983). Analyses were performed in an Olympus CX31RBSFA photographic microscope according to the semiquantitative method proposed by Schwaiger et al. (1997). The magnification was $100 \mathrm{x} /$ 1,30 oil, type of immersion medium was microscopy immersion oil acquired by Merck. The software was Axio Vision Rel. 4.6, with camera AxioCam MRv.

\subsection{Quantitative analysis of branchial alterations}

For morphological analysis and gill alterations, 30 random fields per animal were evaluated under a light microscope at a total magnification of 40x (Olympus CX31RBSFA) according to the semiquantitative method proposed by Schwaiger et al. (1997). An increasing scale of Histological Alteration Index (HAl), depending on the degree of severity of the injuries as described by Mallat (1985): Level $0=$ no histological change; Level $1=$ mild changes; Level 2= moderate and specific changes; Level 3= severe and extensive alterations. The data obtained were analyzed for normality using the Kolmogorov-Smirnov test. Subsequently, they were subjected to analysis of variance one-way (ANOVA) followed by the post-test of Tukey. The significance level adopted was $5 \%$ and the results were expressed as mean \pm standard error.

\section{Results}

\subsection{Scanning Electron Microscopy}

In the control group, the gills had primary and secondary lamellae devoid of alterations (Fig. 1a). The epithelial surface of microridges is composed of polygonal cells (paved cells), with well-defined contours, similar to fingerprints, which characterizes the normal appearance of these folds (Fig. 1b). In the group exposed to 50 $\mu \mathrm{g} / \mathrm{L}$ of metformin, hypertrophy of the primary lamellae was observed (Fig. 1c), and the microridges were visible but presented a differentiated shape (Fig. 1d). After exposure to $100 \mu \mathrm{g} / \mathrm{L}$, hypertrophy was observed in the primary and secondary lamellae (Fig. 1e), as well as a decrease in microridges (Fig. 1f). At a concentration of $1 \mathrm{mg} / \mathrm{L}$, hypertrophy of the primary and secondary lamellae was also observed (Fig. 1g) and the microridges showed severe deformity (Fig. 1h).

At the concentration of $10 \mathrm{mg} / \mathrm{L}$, it was possible to observe excessive hypertrophy of the primary and secondary lamellae (Figs. 2a-f), total secondary lamellar fusion (Figs. 2b-d), primary lamellar fusion (Fig. 2e), and total loss of the microridges (Figs. $2 \mathrm{~g}$ and $\mathrm{h}$ ).

Figure 1

Fig. 1 Scanning electron microscopy of gills of Astyanax lacustris exposed to different concentrations of metformin. (a and b) Control, (c and d) $50 \mu \mathrm{g} / \mathrm{L}$, (e and f) 100 $\mathrm{g} / \mathrm{L}$ and (g and h) $1 \mathrm{mg} / \mathrm{L}$. (PL) Primary lamellae; (SL); Secondary lamellae; (MD) Microridges; (PLH) Primary lamella hypertrophy (SLH); Secondary lamella hypertrophy. Bars: $50 \mu \mathrm{m}$ 
Figure 2

Fig. 2 Scanning electron microscopy of Astyanax lacustris gills exposed to a concentration of $10 \mathrm{mg} / \mathrm{L}$ of metformin (a-h). (PLH) Primary lamella hypertrophy; (SLH) Secondary lamella hypertrophy; (SLF) Secondary lamella fusion; (PLF) Primary lamella fusion; (MD) Microridges. Bars: a, b, d, e=50 $\mu \mathrm{m} ; \mathrm{c}=25 \mu \mathrm{m} ; \mathrm{f}=15 \mu \mathrm{m} ; \mathrm{h}=5 \mu \mathrm{m}$

\subsection{Histological analysis}

Histological analysis revealed changes such as telangiectasia (Figs. 3b and h), bleeding (Figs. 3b and c), primary lamellar fusion (Fig. 3d), vacuolization (Fig. 3e), hyperplasia (Fig. 3f) and secondary lamellar fusion (Fig. 3g).

Figure 3

Fig. 3 Photomicrograph of Astyanax lacustris gills exposed to different concentrations of metformin and stained with hematoxylin and eosin. (a) Control, (b,c,d,h) 10 mg/L, (f) 100 mg/L, (g) 50 mg/L. (PL) Primary lamellae; (SL); Secondary lamellae; (T) Telangiectasia; (B) Bleeding; (E) Edema; (PLF) Primary lamella fusion; (SLF) Secondary lamella fusion; (V) Vacuumization; (HY) Hyperplasia. Bars: $50 \mu \mathrm{m}$

Analyzing the averages of the Mean Values of Changes (M.V.C.) it was possible to observe a dose-dependence relationship for hyperplasia (Fig. 4a) and lamellar fusion (Fig. 4b) alterations, while for telangiectasia this correlation was not observed (Fig. 4c).

Figure 4

Fig. 4 Mean values of changes (M.V.C.) of alterations in Astyanax lacustris gills in relation to metformin concentration. $\mathrm{p}<0.05$ when compared to the control group

When compared statistically, all concentrations tested showed a significant effect in relation to the control $(p>0.05)$. Changes such as bleeding, edema and vacuolization were only observed in the gills exposed to a concentration of $10 \mathrm{mg} / \mathrm{L}$; therefore, they were only analyzed qualitatively.

\section{Discussion}

The respiratory system is the principal interface between a fish and its aquatic environment. Thus, this organ is highly sensitive to chemicals in water and is considered the primary target organ for contaminants (Camargo and Martinez, 2007). Several types of gill impairment have been documented in fish experimentally exposed to contaminants (Thophon et al., 2003; Hassaninezhad et al., 2014; Rodrigues et al., 2017, Zafra-Lemos et. al., 2021). Results of the present study make it evident that even low environmental concentrations of the drug metformin lead to cellular reactions in the gills of $A$. lacustris, which should be considered as an indication of risk from this substance to fish. Some structure remodeling in gills may represent adaptive strategies by which the fish maintains physiological functions (Tkatcheva et al., 2004; Richards, 2011), but the histopathological lesions, as described in the present study, indicated that fish were affected by the exposure to metformin.

The microridges are "fingerprint"-patterned structures commonly found on the branchial surface of the fish (Karlsson, 1983; Eiras-Stofella et al., 2001), including fish from the genus Astyanax (Lopes et al., 2017). An Factin-based cytoskeleton is the underlying core structural component of those structures. The widespread distribution of microridges among various species and tissues indicates that they have important and common 
roles in healthy organisms (Eiras-Stofella et al., 2001; Depasquale, 2018). The function of microridges is not known, although several roles for these structures have been proposed, such as providing structural support to stabilize the enveloping mucus layer of epithelia and mechanical strength against abrasion (Sperry and Wassersug, 1976; Wilson and Laurent, 2002; Ba-Omar et al., 2014). They may even serve as a means of increasing the surface area of cells for absorption purposes (Lam et al., 2015) or possibly act as a stable reserve of pre-polymerized F-actin (Sharma et al., 2008).

Various environmental pollutants are known to affect gill morphology, including alterations in the microridges. In Danio rerio exposed to non-ionized ammonia, microdigits were lost (Al-Zaidan, 2013). A similar effect was seen in fish of the disparate Aphanius species exposed to $3 \mu \mathrm{g} / \mathrm{l}$ of deltamethrin (Al-Ghanbousi et al., 2012), Channa punctata exposed to trace metals (Pandey et al., 2008) and Oreochromis sp. exposed to lead ions (Aldoghachi et al., 2015). Metformin at the cellular level is known to cause inhibition of Complex I of the mitochondrial respiratory chain, which results in a decline in ATP production (Faure et al., 2018). ATP decline may affect dissociations between cytoskeletal proteins, which could explain the decrease and loss of microridges as observed in our analyses (Gov and Safran, 2004).

According to Skidmore and Tovell (1972), the increased adhesion between epithelial cells and the pillar cell support system, associated with the integrity of the secondary lamella structure, can lead to lamellar fusion. On the other hand, it can also occur because of lamellar hyperplasia, due to the union of lamellar capillaries within a mass of hyperplastic epithelium (Rajbanshi and Gupta, 1988). Pereira et al. (2013) studied the histological changes in the gills of Oreochromis niloticus as biomarkers, and they observed the presence of edema, fusion of primary and secondary lamellae, and telangiectasia, lesions that occurred as adaptive biological responses to low-quality water and in an attempt to maintain their physiological functions (Laurent and Perry, 1991). Specimens of Astyanax lacustris had a significant increase in the extension of the gill tissue when exposed to Dormex ${ }^{R}$ herbicide, resulting in lamellar fusion and hyperplasia of the gills in all the concentrations and exposure times, in comparison with the control group (Zafra-Lemos et al., 2021).

For Reis et al. (2009), the lamellar fusion observed in the gills of Oreochromis niloticus may have resulted from compensatory defense mechanisms, but which may compromise the branchial function, depending on the severity of the process. Takashima and Hibiya (1995) attributed the occurrence of mucous cell hyperplasia as a consequence of a chronic defensive response (Mohamad et al., 2021), or due to an increase in cell and tissue functions caused by physiological changes (Takashima and Hibiya 1995; Mohamad et al., 2021). Lamellar hyperplasia is a long-term response of Malpighian cells. These cells are mainly derived from the primary lamellae and accumulate on the anterior edge of the secondary lamella, known as "lubrication" of the lamella. Eventually, the entire interlamellar space can be filled with new cells; as a result, the respiratory area is greatly reduced. However, even with severe damage to the respiratory epithelium, fish survival will not be compromised, as long as these animals live at low temperatures and at high oxygen levels (Roberts, 2012; Salles, 2017).

Disorders involving changes in the circulatory system were found in individuals exposed to metformin; among them were telangiectasia, edema and bleeding. These changes are associated with variations in blood flow in the organ and commonly appear soon after exposure to a toxic agent (Barišić et al., 2015). In the present study, telangiectasia was observed at all drug concentrations, with the highest concentration coinciding with the highest degree of alteration. Intralamellar edema and bleeding were observed at the highest concentration of metformin $(10 \mathrm{mg} / \mathrm{L})$. Likewise, these changes were observed in Squalius vardarensis coming from rivers near 
mines in Macedonia (Barišić et al., 2015), as well as in Acanthopagrus latus exposed to mercury chloride at different concentrations (Hassaninezhad et al., 2014).

\section{Conclusion}

Despite the indubitable usefulness of metformin in the treatment of diabetes, it has been proven that it causes deterioration of the functional units of the respiratory system, so the potential toxicological effects of this drug on fish should be taken into consideration. Monitoring and other studies must be carefully considered, since it is clear that metformin is a very common water contaminant, but research studies have not yet provided a full view of its effects on gills and how this relates to broader complications, such as effects on population sustainability.

\section{Statements \& Declarations}

\section{Acknowledgements}

We thank of the Centro de Microscopia (CMI) of Complexo de Centrais de Apoio à pesquisa (COMCAP) at the Universidade Estadual de Maringá (UEM), Maringá, PR in processing material used and assistance in handling the equipment. This work was supported by the Coordenação de Aperfeiçoamento de Pessoal de Nível Superior (CAPES).

\section{Funding Information}

This study was financed by CAPES (Coordenadoria de Aperfeiçoamento de Ensino Superior).

\section{Competing Interests}

Authors declare they have no conflict of interests.

\section{Author Contributions}

All authors discussed the results and contributed to the final manuscript. Luciana Andreia Borin-Carvalho, Pablo Americo Barbieri and Ana Luiza de Brito Portela-Castro conceived of the presented idea. Material preparation, data collection and analysis were performed by Pablo Americo Barbieri, Luara Lupepsa, Rafael Fernando de Melo, and Brennda Ribeiro Paupitz. The manuscript was written by Pablo Americo Barbieri and Adriana Aparecida Sinópolis Gigliolli with support from Luciana Andreia Borin-Carvalho, Ana Luiza de Brito PortelaCastro, Eneri Vieira de Souza Leite Mello and Isabelle Pereira Mari-Ribeiro. All authors read and approved the final manuscript.

\section{Ethics approval}

Ethical approval for this study was obtained from Ethics Committee on the Use of Animals (CEUA - State University of Maringá, Paraná, Brazil) under decision number 6409140218.

\section{References}

1. Abhilash TN (2012) Pharmaceuticals in Environment: a review on its effect. Res J Chem Sci 2(1):103-105 
2. Aldoghachi MA, Azirum MS, Yusoff I, Ashraf MA (2015) Ultrastructural effects on gill tissues induced in red tilapia. sp by a waterborne lead exposure Saudi J Biol Sci 23:634-641

3. Al-Ghanbousi R, Ba-Omar T, Victor R (2012) Effect of deltamethrin on the gills of. A microscopic study Tissue Cell 44(1):7-14

4. Al-Zaidan AS, Endo M, Maita M, Gonçalves AT, Futami K, Katagiri T (2013) A toxicity bioassay study concerning the effect of un-ionized ammonia on the mucus cells response originating from the gills of zebrafish. Fish Sci 79:129-142. Doi:10.1007/s12562-012-0573-6

5. Barišić J, Dragun Z, Ramani S, Marijić VF, Krasnići N, Čož-Rakovac R, Kostov V, Rebok K, Jordanova M (2015) Evaluation of histopathological alterations in the gills of Vardar chub (. Karaman) as an indicator of river pollution Ecotoxicol Environ Saf 118:158-166

6. Ba-Omar TA, Al-Jardani S, Victor R (2014) Effects of pesticide temephos on the gills of. (Pisces: Cyprinodontidae) Tissue Cell 43(1):29-38

7. Bradley PM, Journey CA, Button DT, Daren M, Carlisle JM, Clark BJ, Mahler N, Nakagaki SL, Qi IR, Waite PC (2016) Metformin and Other Pharmaceuticals Widespread in Wadeable Streams of the Southeastern United States. Environ Sci Technol 3:243-249

8. Camargo MMP, Martinez CBR (2007) Histopathology of gills, kidney and liver of a Neotropical fish caged in an urban stream. Neotrop Ichthyol 53:327-336

9. Crago J, Bui C, Grewal S, Schlenk D (2016) Age-dependent effects in fathead minnows from the anti-diabetic drug metformin. Gen Comp Endocrinol 232:185-190. https://doi.org/10.1016/j.ygcen.2015.12.030

10. Depasquale JA (2018) ActinMicroridges.Anat.Rec,301,2037-2050.https://doi.org/10.1002/ar.23965

11. Dumitrescu R, Mehedintu C, Briceag I, Purcarea VL, Hudita D, Davila C (2015) Metformin-Clinical Pharmacology in PCOs. J Med Life 8(2):187-192

12. 1

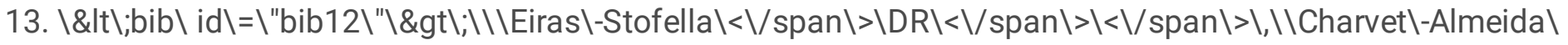

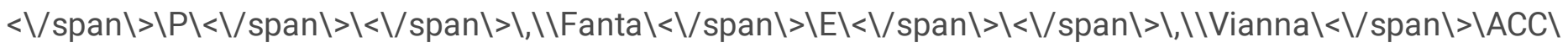
$<\backslash$ span $\backslash>\backslash<\backslash$ span $\backslash>\backslash<\backslash$ /aug $\backslash>\backslash, \mid 2001 \backslash<\backslash /$ span Surfaceultrastructureofthegillsofthemullets $\backslash$ Mugil $\mid$ curema $|<| / i|>1| M \mid$, . $\mid$ liza $|<1 / i|>a n d|M|$. $\mid<1 /$ span $|>| \mid$ platanus $|<1 / i|>\mid$ Mugilidae $|<| /$ span Pisces

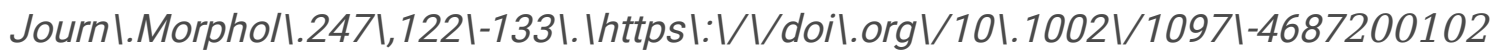
2471:2|\&/t|;1221:|:AIDI-JMOR1007|\&gtl;31.01.COl;2|-5|<1/span |>|\&|t|;|/bib|\&gt|;|<1/p|>

14. Faure M, Bertoldo MJ, Khoueiry R, Bongrani A, Brion F, Giulivi C, Dupont J, Froment P (2018) MetformininReproductiveBiology.Front.Endocrinol.https://doi.org/10.3389/fendo.2018.00675

15. Fatta-Kassinos D, Meric S, Nikolaou A (2011) Pharmaceutical Residues in Environmental Waters and Wastewater: Current State of Knowledge and Future Research. Anal Bioanal Chem 399:251-275

16. https://doi.org/10.1007/s00216-010-4300-9

17. Gigliolli AAS, Lapenta AS, Ruvolo-Takasusuki MCC, Abrahão J, Conte H (2015) Morpho-functional characterization and esterase patterns of the midgut of. Herbst 1797 (Coleoptera: Tenebrionidae) parasitized by Gregarina cuneate (Apicomplexa: Eugregarinidae) Micron 76:68-78

18. Gov NS, Safran SA (2004) Red blood cell membrane fluctuations and shape controlled by ATP-induced cytoskeletal defects. Biophys J. https://doi.org/10.1529/biophysj.104.045328. 88,1859-1874 
19. Hassaninezhad L, Safahieh A, Salamat N, Savari A, Majd NE (2014) Assessment of gill pathological responses in the tropical fish yellowfin seabream of Persian Gulf under mercury exposure. Toxicol Rep 1:621-628

20. Heberer T (2002) Occurrence, fate, and removal of pharmaceutical residues in the aquatic environment: a review of recent research data. Toxicol Lett 131:5-17

21. Ibáñez M, Gracia-Lor E, Bijlsma L, Morales E, Pastor L, Hernández F (2013) Removal of emerging contaminants in sewage water subjected to advanced oxidation with ozone. J Hazard Mater 260:389-398

22. Inoue LAKA, Afonso LOB, Iwama GK, Moraes G (2005) Effects of clove oil on the stress response of matrinxã (Brycon cephalus) subjected to transport.Acta Amaz.35(2).https://doi.org/10.1590/S004459672005000200018

23. Johnson NP (2014) Metformin use in women with polycystic ovary syndrome. Annals Transl Med 2(6):56

24. Junqueira LCU, Junqueira LMMS (1983) Técnicas Básicas de Citologia e Histologia, primeira edição. Santos, São Paulo

25. Karlsson L (1983) Gill morphology in the zebrafish,. (Hamilton-Buchanan) J Fish Biol 23:511-524. https://doi.org/10.1111/j.1095-8649.1983.tb02931.x

26. Lam P, Mangos S, Green JM, Reiser J, Huttenlocher A (2015) In Vivo Imaging and Characterization of Actin Microridges.Plos One.https://doi.org/10.1371/journal.pone.0115639

27. Laurent P, Perry SF (1991) Environmental effects on fish gill morphology. Physiol Zool 64:4-25

28. Lopes FP, Pereira BF, Alves RMS, Valim JRT, Figueiredo FAT, Pitol DL, Caetano FH (2017) Ultramorphological changes in gill rakers of. (Characidae) kept in contaminated environments Fish Physiol Biochem 43:10331041. Doi:10.1007/s10695-017-0350-7

29. MacLaren RD, Wisniewski K, MacLaren C (2018) Environmental concentrations of metformin exposure affect aggressive behavior in the Siamese fighting fish. Betta splendens Plos One 13(5):e0197259

30. Mallatt $J$ (1985) Fish gill structural changes induced by toxicants and other irritants: a statistical review. Fish Aquat Sci 42:630-648

31. Meador JP, Yeh A, Gallagher EP (2018) Adverse metabolic effects in fish exposed to contaminants of emerging concern in the field and laboratory. Environm Pollut 236:850-861.

https://doi.org/10.1016/j.envpol.2018.02.007

32. Moermond CT, Smit CE (2016) Derivation of water quality standards for carbamazepine, metoprolol, and metformin and comparison with monitoring data. Environ Toxicol Chem 35:882-888.

https://doi.org/10.1002/etc.3178

33. Liew HJ, Zainuddin RA, Rahmah S, Waiho K, Ghaffar MA, Nhan HT, Loh JY, Lim LS, Chang Y, Liang L (2021) High environmental temperature and low pH stress alter the gill phenotypic plasticity of Hoven's carp Leptobarbus hoevenii.J. Fish Biol.99,206-218.https://doi.org/10.1111/jfb.14712

34. Niemuth NJ, Klaper RD (2015) Emerging wastewaer contaminant metformin causes intersex and reduced fecundity in fish. Chemosphere 135:38-45

35. Oosterhuis M, Sacher F, Ter Laak TL (2013) Prediction of concentration levels of metformin and other high consumption pharmaceuticals in wastewater and regional surface water based on sales data. Sci Total Environ 442:380-388 
36. Pandey S, Parvez S, Ansari RA, Ali M, Kaur M, Hayat F, Ahmad F, Raisuddin S (2008) Effects of exposure to multiple trace metals on biochemical, histological and ultrastructural features of gills of a freshwater fish. Channa punctata Bloch Chem Biol Interact 174:183-192. Doi:10.1016/j.cbi.2008.05.014

37. Patel M, Kumar R, Kishor K, Mlsna T, Pittman CU Jr (2019) Pharmaceuticals of Emerging Concern in Aquatic Systems: Chemistry, Occurrence, Effects, and Removal Methods. Chem Rev 119(6):3510-3673

38. Pereira S, Pinto AL, Cortes R, Fontaínhas-Fernandes A, Coimbra AM, Monteiro SM (2013) Gill histopathological and oxidative stress evaluation in native fish capturedin Portuguese northwestern rivers. Ecotoxicol Environ Saf 90:157-166

39. Rajhanshi VK, Gupta AK (1988) Alterations in the architecture of the gill surface produced by water-borne copper in. (BLOCH) Acta Hydrochim Hydrobiol 16(3):325-331. https://doi.org/10.1002/aheh.19880160314

40. Reis AB, Sant'ana DMG, de Azevedo JF, Merlini LS, Araújo EJA (2009) Alterações do epitélio branquial e das lamelas de tilápias (. Pesq Vet Bras 29(4):303-311

41. Ribeiro CAO, Filipack F, Mela M, Silva PH, Randi MAF, Costa JRA, Pelletier E (2006) Hematological findings in neotropical fish. exposed to subchronic and dietary doses of methylmercury inorganic lead and tributyltin chloride Environ Res 101:74-80. https://doi.org/10.1016/j.envres.2005.11.005

42. Richards JG (2011) Physiological, behavioral and biochemical adaptations of intertidal fishes to hypoxia. J Exp Biol 214(2):191-199. https://doi.org/10.1242/jeb.047951

43. Roberts RJ (2012) Fish Pathology, Idaho. Wiley-Blackwell, pp 17-61

44. Rodrigues S, Antunes SC, Nunes B, Correia AT (2017) Histological alterations in gills and liver of rainbow trout (. Environ Toxicol Pharmacol 53:164-176. https://doi.org/10.1016/j.etap.2017.05.012

45. Sahra IB, Laurent K, Giuliano S, Larbret F, Ponzio G, Gounon P, Marchand-Brustel YL, Giorgetti-Peraldi S, Cormont M, Bertolotto C, Deckert M, Auberger P, Tanti JF, Bost F (2010) Targeting Cancer Cell Metabolism: The Combination of Metformin and 2-Deoxyglucose Induces p53-Dependent Apoptosis in Prostate Cancer Cells. Cancer Res 70(6):2465-2475. Doi:10.1158/0008-5472.CAN-09-2782

46. Sales CF, Santos KPE, de Ribeiro RIM (2017) RG,Proliferation,survivalandcelldeathinfishgillsremodeling:Frominjurytorecovery.FishShellfishlmmunol.68,1018.https://doi.org/10.1016/j.fsi.2017.07.001

47. Santos LHMLM, Araújo AN, Fachini A, Pena A, Delerue-Matos C, Montenegro MCBSM (2010) Ecotoxicological aspects related to the presence of pharmaceuticals in the aquatic environment. J Hazard Mater 175(1-3):45-95

48. Santos LHMLM, Gros M, Rodriguez-Mozaz S, Delerue-Matos C, Pena A, Barceló D, Montenegro MCBSM (2013) Contribution of hospital effluents to the load of pharmaceuticals in urban wastewaters: identification of ecologically relevant pharmaceuticals. Sci Total Environ 461:302-316

49. Saraei P, Asadi I, Kakar MA, Moradi-Kor N (2019) The beneficial effects of metformin on cancer prevention and therapy: a comprehensive review of recent advances. Cancer Manag Res 11:3295-3313.

Doi:10.2147/CMAR.S200059

50. Scheuer W, Friess T, Burtscher H, Bossenmaier B, Endl J, Hasmann M (2009) Strongly enhanced antitumor activity of trastuzumab and pertuzumab combination treatment on HER2-positive human xenograft tumor models. Cancer Res 69(24):9330-9336. Doi:10.1158/0008-5472.CAN-08-4597 
51. Scheurer M, Michel A, Brauch HJ, Ruck W, Sacher F (2012) Occurrence and fate of the antidiabetic drug metformin and its metabolite guanylurea in the environment and during drinking water treatment. Water Res 46(15):4790-4802. Doi:10.1016/j.watres.2012.06.019

52. Schwaiger J, Wanke R, Adam S, Pawert M, Honnen W, Triebskorn R (1997) The use of histopathological indicators to evaluate contaminant related stress in fish. J aquat ecosyst stress recovery 6(1):75-86

53. Sharma A, Anderson KI, Muller DJ (2005) Actin microridges characterized by laser scanning confocal and atomic force microscopy. FEBS Lett 579:2001-2008. https://doi.org/10.1016/j.febslet.2005.02.049

54. Sharma VK, Nautuyal V, Kapil K, Goel K, Sharma A (2010) Assessment of Thermal Stability of Metformin Hydrochloride. Orient J Chem 22(5):3561-3566

55. Shao B, Chen D, Zhang J, Wu Y, Sun C (2009) Determination of 76 pharmaceutical drugs by liquid chromatography-tandem mass spectrometry in slaughterhouse wastewater. J Chromatogr 1216:83128318

56. Skidmore JF, Tovell PWA (1972) Toxicity effects of zinc sulfate on the gills of rainbow trout. Water Res 6:217-230

57. Sperry DG, Wassersug RJ (1976) A proposed function for microridges on epithelial cells. Anat Rec 185:253258. Doi:10.1002/ar.1091850212

58. Stuart M, Lapworth D, Crane E, Hart A (2012) Review of risk from potential emerging contaminants in UK groundwater. Sci Total Environ 416:1-21. https://doi.org/10.1016/j.scitotenv.2011.11.072

59. Takashima F, Hibiya T (1995) An Atlas of Fish Histology. Normal and Pathological Features, second edn. Kodansha Ltd., Tokyo

60. Thophon S, Kruatrachuea M, Upatham ES, Sahaphong S, Jaritkhuanc S (2003) Histopathological alterations of white seabass,. in acute and subchronic cadmium exposure Environ Pollut 121(3):307-320

61. Tkatcheva V, Hyvarinen H, Kukkonen J, Ryzhkov LP, Holopainen IJ (2004) Toxic effects of mining effluents on fish gills in a subarctic lake system in NW Russia. Ecotoxicol Environ Saf 57:278-289. http://dx.doi. org/10.1016/S0147-6513(03)00079-4

62. Trautwein C, Berset JD, Wolschke H, Kümmerer K (2014) Occurrence of the antidiabetic drug Metformin and its ultimate transformation product Guanylurea in several compartments of the aquatic cycle. Environ Int 70:203-212

63. Trautwein C, Kümmerer K (2011) IncompleteaerobicdegradationoftheantidiabeticdrugMetforminandidentificationofthebacterialdeadendtransformationproductGuanylurea.Chemosphere.85,765-

73.http://dx.doi.org/10.1016/j.chemosphere.2011.06.057

64. Wilson JM, Laurent P (2002) Fish Gill Morphology: Inside Out. J Exp Zool 293:192-213

\section{Figures}

\section{Figure 1}


Scanning electron microscopy of gills of Astyanax lacustris exposed to different concentrations of metformin. (a and b) Control, (c and d) $50 \mu \mathrm{g} / \mathrm{L}$, (e and f) 100 $\mathrm{gg} / \mathrm{L}$ and (g and h) $1 \mathrm{mg} / \mathrm{L}$. (PL) Primary lamellae; (SL);

Secondary lamellae; (MD) Microridges; (PLH) Primary lamella hypertrophy (SLH); Secondary lamella hypertrophy. Bars: $50 \mu \mathrm{m}$

\section{Figure 2}

Scanning electron microscopy of Astyanax lacustris gills exposed to a concentration of $10 \mathrm{mg} / \mathrm{L}$ of metformin (a-h). (PLH) Primary lamella hypertrophy; (SLH) Secondary lamella hypertrophy; (SLF) Secondary lamella fusion; (PLF) Primary lamella fusion; (MD) Microridges. Bars: $a, b, d, e=50 \mu m ; c=25 \mu m ; f=15 \mu m ; h=5 \mu m$

\section{Figure 3}

Photomicrograph of Astyanax lacustris gills exposed to different concentrations of metformin and stained with hematoxylin and eosin. (a) Control, (b,c,d,h) $10 \mathrm{mg} / \mathrm{L}$, (f) $100 \mathrm{mg} / \mathrm{L}$, (g) $50 \mathrm{mg} / \mathrm{L}$. (PL) Primary lamellae; (SL); Secondary lamellae; (T) Telangiectasia; (B) Bleeding; (E) Edema; (PLF) Primary lamella fusion; (SLF) Secondary lamella fusion; (V) Vacuumization; (HY) Hyperplasia. Bars: 50 $\mathrm{mm}$

\section{Figure 4}

Mean values of changes (M.V.C.) of alterations in Astyanax lacustris gills in relation to metformin concentration. $\mathrm{p}<0.05$ when compared to the control group

\section{Supplementary Files}

This is a list of supplementary files associated with this preprint. Click to download.

- graphicabstract.tif 